\title{
The 1906 San Francisco Earthquake: A Centennial Contemplation
}

\author{
Jeffrey L. Arnold, MD
}

\begin{abstract}
"Not in bistory has a modern imperial city been so completely destroyed. San Francisco is gone. Nothing remains of it but memories and a fringe of dwelling-houses on its outskirts. Its industrial section is wiped out. Its business section is wiped out. Its social and residential section is wiped out."

Jack London, $1906^{1}$
\end{abstract}

The publication of this issue of Prehospital and Disaster Medicine coincides with the centennial of the 1906 Great San Francisco Earthquake. The 1906 San Francisco Earthquake does not rank with the larger earthquakes in world history and is not even the largest earthquake in US history. In fact, readers of this journal will recall many recent earthquakes that produced exponentially greater health damage in Kobe, Japan (1995), Chi-Chi, Taiwan (1999), Marmara, Turkey (1999), Gujarat, India (2001), Bam, Iran (2003), South Asia (2004), and Kashmir, Pakistan (2005).

Nevertheless, the 1906 San Francisco Earthquake was one of the most notorious disasters of its time. In that age of telephone and telegraph, news of the Great Earthquake in the city widely celebrated as the "Paris of the West", rapidly spread around the globe. The secondary Great Fire remains the worst urban fire disaster in United States history and was unequalled in the world until the bombing raids of World War II. ${ }^{2}$ Until Hurricane Katrina last year, the 1906 San Francisco Earthquake was the largest disaster caused by natural events in US history. Finally, the 1906 San Francisco Earthquake offers several lessons learned in disaster medicine and emergency management that are worth re-visiting today. ${ }^{2}$

An understanding of this disaster is facilitated by the conceptual framework developed by the Task Force in Quality Control in Disaster Medicine. ${ }^{3}$

The hazard underlying the 1906 San Francisco Earthquake was the northernmost segment of the San Andreas fault, spanning 296 miles from San Juan Bautista to Cape Mendocino, California. ${ }^{4}$

The primary event was the rupture of the fault line (earthquake) that occurred at 05:12 hours (h) on 18 April 1906. The epicenter most likely was in the Pacific Ocean, two miles west of San Francisco's Golden Gate Park. The magnitude of the quake has been estimated at 7.7-7.9 Richter. ${ }^{4}$ Much of the city of San Francisco then and now was constructed on three unstable surfaces: steep hillsides, rolling sand dunes, and land-filled marshes. ${ }^{5}$

The secondary event was the Great Fire that began at 52 locations across the city within 30 minutes after the quake and continued to rage for three days. ${ }^{2}$ Many fires were caused by ruptured gas lines, particularly in collapsed structures in lowlying areas built on land-fill.

The population-at-risk included the 410,000 people who lived in San Francisco, as well as those in communities up and down the fault segment from Shelter Cove to San Juan Bautista. ${ }^{2,4}$ Because the earthquake occurred early in the morning, most of the population at risk was sleeping indoors when the quake struck.

The primary earthquake and an initial aftershock damaged buildings throughout San Francisco, especially in the low-lying areas built on former marshes. The City Hall, the Grand Opera House, and several firehouses, churches, and hotels were promptly demolished. ${ }^{2,5,6}$ Buildings tending to collapse included poorly built, wooden structures, those with poorly built brick chimneys, and those constructed with unreinforced masonry. The quake also knocked out the city's underground water mains and the critical pipeline between the city and its nearby reservoirs, local telephones, the telegraph cable that connected San Francisco with the rest of the US, and the public transportation system (cable cars and street cars). In addition, the quake demolished many structures in communities outside of San Francisco, including most of the buildings in Santa Rosa, the main building at Agnews State Hospital for the Insane in Santa Clara County, and many buildings on the campus of Stanford University. ${ }^{2}$

Despite the widespread damage from the earthquake, the secondary fire caused the greatest damage. Because many buildings collapsed in low-lying areas, many fires started there as well, spreading to buildings and homes not initially destroyed by the quake, including the 16-story Call Building, the Hearst Building, the Chronicle Building, and the famous Palace Hotel. ${ }^{2}$ Ultimately, the fire storm consumed 522 city blocks, four square miles of the city, and 28,188 buildings. 2,4

The 1906 San Francisco Earthquake killed $>3,000$ persons and injured approximately $225,000 .{ }^{4}$ Large numbers of people perished in several structural collapses, including 80 persons in the Valencia Hotel, 60 in the Royal Hotel, and 40 in Corona House Hotel. Many of those entrapped in structural collapses, burned to death in the ensuing firestorm. In addition, approximately 190 people died outside of the city, including an estimated 100 patients at Agnews State Hospital for the Insane. In San Francisco, an estimated 250,000 people were rendered homeless and 300,000 evacuated the city. ${ }^{2}$

At $06: 30 \mathrm{~h}$ on 18 April, US Army General Frederick Funston ordered all available local troops to report to San Francisco Mayor Eugene Schmitz, in order to enforce security in the city. Although there was no evidence of looting, within hours of the quake, Mayor Schmitz issued an unconstitutional proclamation that authorized the military and police to "shoot to kill" looters or those engaged in any other crime on the spot. ${ }^{2,7}$ An estimated 10-100 suspects were killed over the next several days. ${ }^{2}$ In addition to helping maintain public order, the troops distributed food and clothing, set up camps for the homeless, demolished ruined buildings, and cleared the streets of debris. 
With their fire chief killed by the initial quake and only a meager water supply, firefighters were unable to contain the spreading fires. General Funston and civilian authorities decided to dynamite buildings in an attempt to create firebreaks at key locations. Not only were the firefighters untrained in this technique, but the army sent black gun powder instead of the requested dynamite. As a result, the detonations not only failed to stop the fires, but actually set more buildings ablaze, feeding the voracious conflagration. By nightfall on 18 April, the fire had outflanked the misconceived attempts to contain it. ${ }^{2,7}$

Over the next two days, the fire razed a large portion of the city, although it did spare much of the waterfront where US Navy firefighters, two naval fireboats, and a destroyer successfully limited its spread. Ultimately, the Mayor, the Fire Department, and the Army were unwilling to admit responsibility for their collective mistakes, instead blaming each other, continuing the administrative confusion that marked their emergency response. ${ }^{7}$

After the quake, bystanders immediately began to rescue victims from damaged buildings. A clergyman set up an emergency hospital in an auditorium on Grove Street. By 08:00 h, it had 287 patients. ${ }^{2}$ The site was abandoned by mid-day because of the encroaching fire. At 10:30 h, the USS Preble from Mare Island sent a hospital party ashore to assist the injured at Harbor Emergency Hospital. At 13:00 h, St. Mary's Hospital was abandoned due to nearby fire and its patients were evacuated to Oakland on the ferryboat, "Modoc". 6 At least one entrapped man was killed by a bystander in a mercy killing as fire approached. ${ }^{2}$ At 17:00 h, with the city morgue and pistol range unable to hold more bodies, the police buried at least 50 corpses in Portsmouth Square. ${ }^{6}$

In the face of spreading fire, people immediately began to flee the city with what few possessions they could carry, evacuating by various combinations of boat, train, and foot. The Southern Pacific Railroad reportedly transported 225,000 evacuees in the first week via 129 trains in California, 610 trains to Oakland and Berkeley, and 50 trains to points south of San Francisco. ${ }^{2}$ Ferries transported evacuees to Marin and Alameda Counties and streamers moved people to other parts of the Bay Area. On 19 April, 176 city prisoners were evacuated to Alcatraz. ${ }^{6}$ At Agnews State Hospital for the Insane, surviving patients were chained to trees to prevent their escape. ${ }^{2}$

On 19 April, US Secretary of War, William H. Taft ordered 200,000 rations from the Vancouver Barracks and all hospital, wall, and conical tents from military posts throughout the western US be sent to San Francisco. ${ }^{6}$ Ad boc camps for displaced persons were established throughout the Bay Area, particularly in Oakland. The influx of displaced persons permanently altered the composition of these commu- nities and led to the urbanization of the Bay Area. ${ }^{7}$ In San Francisco, military-style barracks were constructed to house the homeless, but two months after the quake, only 18,000 of the 43,000 homeless elected to reside there. ${ }^{2}$

Newspapers perpetuated myths of mass destruction. The Oakland Enquirer reported that the Cliff House had fallen into the ocean, while its rival, the Oakland Herald wrote that a tidal wave had struck San Diego. Meanwhile, rumors swept San Francisco that Chicago had been swallowed up by Lake Michigan. ${ }^{2}$

The initial emergency response may have been most aptly summarized by Jack London in his report for Collier's Magazine: "There was no opposing the flames. There was no organization, no communication. All the cunning adjustments of a twentieth century city had been smashed by the earthquake."

The earthquake also was a watershed event for disaster science. Three days after the quake, California Governor George Pardee established a State Earthquake Investigation Commission, comprised of eight members who were charged with studying surface changes, geophysics, and earthquake arrival times at various locations. ${ }^{4,5}$ Funded in part by $\$ 5,000$ from the Carnegie Institution, the Commission ultimately recruited the expertise of 21 participants, including Fusakichi Omori, Professor of Seismology at the Imperial University of Tokyo. Ahead of the world, Japan already had established a national seismological society in $1880 .^{5}$

Among the Commission's most important contributions was the observation that the intensity of the shaking in an area correlates with its underlying geologic conditions. In the 1906 San Francisco Earthquake, the strongest shaking occurred in sediment-filled valleys, particularly in the areas of San Francisco reclaimed from the San Francisco Bay and the weakest shaking occurred at bedrock sites. Through the meticulous field-work of two of its members, the Commission also mapped the San Andreas fault. Finally, analysis of 1906 surface displacements and strain led Harry Fielding Reid to formulate his seminal elastic-rebound theory of the origin of earthquakes, in which the earth's crust slowly moves along a fault line creating stored elastic stress that only is relieved by an earthquake. ${ }^{4,5}$

As suggested above, there are many striking similarities and some important differences between the events, damage, and emergency response in this earthquake that occurred 100 years ago and disasters of today. When we consider the possibility of the next major earthquake somewhere in the world, we should also contemplate what we have accomplished in disaster medicine and emergency management these past 100 years and what tasks lay ahead.

References

1. London J: The story of an eyewitness. 05 May 1906. Sonoma State University Website. Available at: http://london.sonoma.edu/Writings/ Journalism/sfearthquake.html Accessed April 16, 2006.

2. Nolte C: The Great Quake: 1906-2006. San Francisco Chronicle Website. Available at: www.sfgate.com/greatquake. Accessed 16 April 2006.

3. Task Force on Quality Control in Disaster Medicine/World Association of Disaster and Emergency Medicine: Health Disaster Management: Guidelines for Evaluation and Research in the "Utstein Style." Prebosp Disast Med 2002;17(Suppl 3):1-177.

4. United States Geological Survey: The Great San Francisco Earthquake. USGS Website. Available at http://quake.wr.usgs.gov/info/1906/. Accessed 16 April 2006

5. Bancroft Library: The 1906 San Francisco Earthquake and Fire. Bancroft Library Website. Available at: http://bancroft.berkeley.edu/collections/earthquakeandfire/index2.html Accessed 16 April 2006.

6. Hansen G: Timeline of the San Francisco Earthquake, April 18-23, 1906. San Francisco Museum Website. Available at www.sfmuseum.org/hist10/06timeline.html Accessed 16 April 2006.

7. Starr K: The quake that broke San Francisco's spirit. The Mercury News Web site. Available at www.mercurynews.com/mld/mercurynews/news/editorial/ 14356028.htm. Accessed 16 April 2006. 